\title{
Cutaneous Metastasis of Head and Neck Malignancy
}

\author{
${ }^{1}$ Henry Emanuel, ${ }^{2}$ Patrick Emanuel
}

\begin{abstract}
Background: Noncutaneous cancers of the head and neck occasionally metastasize to skin. We present a case series of patients with skin metastases from non-cutaneous malignancies of the head and neck. A literature review is presented to assess the morphology, pattern of distribution, and morbidity of skin metastases.
\end{abstract}

Methods: Relevant cases were identified by a dermatopathologist and cases were reviewed. A literature search yielded 94 cases which were also included.

Results: The most common primary site, histology, and location of spread was the thyroid gland $(42 \%)$, squamous cell carcinoma $(42 \%)$, and scalp (25\%) respectively. Skin metastases typically present as a discrete nodules, but the distribution varies. Metastases to skin can occasionally be a patients presenting complaint, but irrespective of timing of presentation portend a poor prognosis.

Conclusion: Skin metastases are clinically rare, and when present typically herald a poor overall prognosis. Information regarding their distribution and clinical presentation is of importance to the surgeon and oncologist.

Keywords: Head and neck cancer, Non-cutaneous cancer, Skin metastasis.

How to cite this article: Emanuel $\mathrm{H}$, Emanuel $\mathrm{P}$. Cutaneous Metastasis of Head and Neck Malignancy. Int J Head Neck Surg 2015;6(2):57-63.

Source of support: Nil

Conflict of interest: None

\section{INTRODUCTION}

Skin metastases (SM) from noncutaneous primary malignancies are uncommon and are seen in only 0.7 to $9 \%$ of patients with internal cancers. ${ }^{1}$ Malignancies of the head and neck account for approximately $15 \%$ of all SM and so such presentations are important for practicing head and neck surgeons to consider. ${ }^{2}$ Typically, SM

\footnotetext{
${ }^{1}$ Registrar, ${ }^{2}$ Assistant Professor

${ }^{1}$ Department of Otorhinolaryngology, Waikato Hospital, Waikato New Zealand

${ }^{2}$ Department of Dermatopathology, Mount Sinai Medical Center, New York, United States

Corresponding Author: Henry Emanuel, Registrar Department of Otorhinolaryngology, Waikato Hospital Waikato, New Zealand, Phone: 64212227620, e-mail: henryemanuel@me.com
}

present sometime after diagnosis of the primary cancer ${ }^{3}$ and can indicate progressive disease, or recurrence of disease. Analogous to SM from other malignancies, SM from head and neck tumors portend dismal prognosis. Median survival is as low as 3 to 6 months from the timeSM present. ${ }^{4,5}$ Given the very poor prognosis, this influences treatment planning and how these patients are to be counselled. Identified risk factors for developing SM from cancers of the head and neck include two or more cervical metastases, or extracapsular spread of nodal metastases in the neck. ${ }^{5}$ Interestingly, the stage of disease is not always a significant predictor for developing SM and thus can sometimes occur early in the course of disease. ${ }^{6}$ In fact, $\mathrm{SM}$ is occasionally the presenting feature of cancer and also carries with it a dismal prognosis (1 year survival $\sim 4 \%) .{ }^{3}$ We further emphasize the importance of thorough skin examination in patients with known cancer, and also suggest investigation of suspicious skin lesions as these may be metastases from occult primary cancers. ${ }^{7-16}$

Large cohorts of patients with SM have been reviewed, and the patterns of their distribution analyzed. ${ }^{17}$ In a review including 59 cases of oral squamous cell carcinoma (SCC), all metastasized to the skin of the face or neck. ${ }^{18}$ Many of these cases exhibited skin involvement contiguous with the primary tumor or metastatic lymph node deposits in the neck. These lesions have clear differences to true metastases with respect to pathogenesis, prognosis and management. More recently, Hussein ${ }^{1}$ reviewed the histological and clinical presentation of SM from various sites throughout the body, and included primary head and neck subsites (thyroid, larynx and salivary gland).

To date, we do not believe there has been a comprehensive review focussing on the morphology and distribution of SM from noncutaneous head and neck cancers that subdivides common subsites the head and neck surgeon encounters. We posit that understanding the clinical presentation of metastatic spread to the skin from head and neck cancers will provide valuable prognostic information, reinforce the need for an adequate skin examination, and potentially provide clues to aid in the localization of a primary tumor in cases where they have not already been found.

\section{METHODS}

A PubMed search for relevant articles was conducted utilizing the MeSH terms: 'neoplasm metastasis', 'head 
and neck neoplasms', and 'skin'. The yield of 85 papers was filtered to exclude non-English languages, cases of cutaneous primary lesions, e.g. melanoma, and those papers focussing on treatment, which was not the intention of this review. Other exclusions made were those primary tumors outside the common practice of otolaryngology/head and neck surgeons including intracranial and distal esophageal tumors. Embase was utilized using the same search terms and exclusions to capture literature that was either very recent, or not yet assigned $\mathrm{MeSH}$ terms. Sixty-three case reports, 10 case series, and 11 review articles were finally gathered that were relevant. Our data are based on 93 cases from all head and neck sites and date from 1972 to present. In addition, we gathered data from the Mount Sinai Medical Center pathology database to find cases of dermal metastases from head and neck (HN) cancers where histopathology was available for the primary tumor and the metastasis. These were examined by a dermatopathologist, to ensure diagnosis, and to exclude those cases where SM was a direct extension from the primary tumor or underlying nodal metastasis. Twelve such cases were identified.

We collated data from the literature (case reports, case series) and our center. Parameters gathered were: age, sex, site of primary tumor, pathological diagnosis, Site and morphology of metastasis, time to metastasis from diagnosis, and end point. Such end points seen were disease-free survival (DFS), died of disease (DOD), dissemination of disease (DISS), died from unrelated causes (DUC) or not specified (NS). Data were arranged by primary tumor site as well as pathology and the data from each organ/site interpreted in order to understand the behavior from each area and tumor type. In addition, we gathered cases of implantation of tumor cells into skin from postsurgical scars or fine needle aspiration (FNA) tracts and hypothesized that these heralded a more favorable prognosis.

\section{RESULTS}

A total of 93 published cases and 12 local cases comprised the 105 cases analyzed. The average age was 59 years (6-91). Both sexes were similarly represented (males = 52 , females $=47$ ), with the remaining ten cases not described in their case series. Data on each tumor subsite is displayed in Table 1.

Excluding theninecases of FNA tract implantation, $7,19-25$ 96 cases of SM are presented. Fifty (51\%) of these presented with SM above the level of the clavicles. The remainder presenting with distant metastases below the clavicle alone $30(31 \%)$ or with disseminated metastases above and below the level of the clavicles 17 (17\%).

\section{THYROID GLAND $7,9,10,12,16,26-49$}

\section{Sites of Metastases}

Thyroid cancers are the most common noncutaneous head and neck cancers to metastasize to skin (44 cases). Of these cases, the scalp is the most common site of metastasis $34 \%$ and when presenting here; always manifest as one or more nodules. Less commonly, tumors arising here develop SM to the neck $18 \%$, the chest $12 \%$, and the face $9 \%$. The remaining $26 \%$ (12 cases) of thyroid malignancies metastasized to distant skin sites outside the head and neck and in 66\% (8) of these there were metastases at distant skin sites without concurrent metastases in the skin of the head and neck. The five exceptions to nodular SM (two cysts, ${ }^{35,48}$ two rashes, ${ }^{43,47}$ one ulcer) ${ }^{41}$ were seen at sites outside the head and neck region in all but one case of erythematous rash of the face ${ }^{43}$ nine cases of skin deposits arising within fine needle aspiration biopsy (FNAB) tracts or post-thyroidectomy scars are reported..$^{7,19-23,25,42}$ As expected the prognosis from this is far better compared to true metastasis from thyroid tumors, with DFS observed up to 6 to 7 years. ${ }^{21}$ Two diseases related death have been reported 10 weeks ${ }^{23}$ and 10 years after implantation ${ }^{25}$ of anaplastic/poorly differentiated tumor cells into skin.

\section{Outcomes by Pathology}

Follicular thyroid carcinoma (FTC) is the most commonly reported tumor of the head and neck to present with SM prior to cancer diagnosis (8/12 cases). In three of these 12 cases, the metastases were present 1 to 2 years prior to cancer diagnosis. ${ }^{7,37}$ Data are sometimes lacking on the outcomes for these patients however death was reported in just $3(25 \%)$ cases (mean 4.5 years from SM), however one case developed wide dissemination of disease without observed death. ${ }^{38}$

Anaplastic and poorly differentiated carcinoma of the thyroid caused death and / or dissemination of disease in all patients where reported (five/six cases). The average time to death was only 3 months following appearance of SM, which manifest at varying times (1 week to 6 months) after cancer diagnosis. Anaplastic thyroid SM have variable locations and are reported in scalp, upper limb, face, chest and abdominal skin.

Medullary thyroid carcinoma caused death or disseminated disease in all but one case (exception died of unrelated causes). Where reported in five of nine cases, mean time to death from disease was 8.9 months following detection of SM. Skin metastases were found in the neck or chest in $9 / 13$ of total SM sites (70\%) and these were seen following cancer diagnosis in all cases (mean time 79 months / 6.6 years). Skin metastases presentation 
Table 1: Behavior of skin metastases from noncutaneous head and neck tumors. Cases in bold represent local cases

\begin{tabular}{|c|c|c|c|c|c|c|c|}
\hline Primary site & References & $\begin{array}{l}\text { No. of } \\
\text { cases }\end{array}$ & Tumor type & Site of SM & $\begin{array}{l}\text { Morphology of } \\
\text { SM }\end{array}$ & $\begin{array}{l}\text { Mean time to } \\
\text { SM }\end{array}$ & Mean outcome \\
\hline Thyroid & $\begin{array}{l}7,9,10,12 \\
16,26-49\end{array}$ & $42+2$ & $\begin{array}{l}\text { Anaplastic } 6(14 \%) \\
\text { Follicular } 12(27 \%) \\
\text { Medullary } 9(20 \%) \\
\text { Papillary } 15+2 \\
(38 \%)\end{array}$ & $\begin{array}{l}\text { Scalp }(34 \%) \\
\text { Neck }(18 \%) \\
\text { Chest }(12 \%) \\
\text { Face (1) (9\%) } \\
\text { Distant (1) } \\
(26 \%)\end{array}$ & $\begin{array}{l}\text { Nodule (1) } \\
(82.5 \%) \\
\text { Rash }(5 \%) \\
\text { Cyst (5\%) } \\
\text { Ulcer }(2.5 \%) \\
\text { NS (1) }(5 \%)\end{array}$ & $\begin{array}{l}50 \text { months } \\
\text { Presentation } \\
8(18.6 \%)\end{array}$ & $\begin{array}{l}\text { DOD } 13 \text { months } \\
(49 \%) \\
\text { DISS }(16 \%) \\
\text { DFS }(7 \%) \\
\text { NS }(28 \%)(1)\end{array}$ \\
\hline Salivary gland & $\begin{array}{l}8,11,13 \\
15,51-59\end{array}$ & $12+5$ & $\begin{array}{l}\text { Adenoid cystic } 3+1 \\
(23 \%) \\
\text { ACC } 1+1(12 \%) \\
\text { MEC } 3+1(23 \%) \\
\text { Myoepithelial CA } 1 \\
(6 \%) \\
\text { Adeno CA } 1+2 \\
(18 \%) \\
\text { Pleomorphic adeno } \\
\text { CA } 2(12 \%) \\
\text { PLGA } 1(6 \%)\end{array}$ & $\begin{array}{l}\text { Face (4) }(31 \%) \\
\text { Scalp (1) } \\
(17 \%) \\
\text { Chest (1) } \\
(14 \%) \\
\text { Distant }(27 \%)\end{array}$ & $\begin{array}{l}\text { Nodule (3) }(66 \%) \\
\text { Plaque (1) }(11 \%) \\
\text { Papule (1) }(11 \%) \\
\text { Cyst }(11 \%) \\
\text { Induration }(11 \%)\end{array}$ & $\begin{array}{l}77.8 \text { months } \\
\text { Presentation } \\
5(38 \%)\end{array}$ & $\begin{array}{l}\text { DOD } 5.75 \text { months } \\
(60 \%) \\
4 \text { and } 6 \text { years } \\
\text { DISS }(15 \%) \\
\text { DFS }(15 \%) \\
(1,3 \text { and } 8 \text { years) } \\
\text { NS } 3+2 / 13\end{array}$ \\
\hline Oral cavity & $57,60,61$ & $5+1$ & $\operatorname{scc} 5+1(100 \%)$ & $\begin{array}{l}\text { Chest }(36 \%) \\
\text { Face }(1) \\
(9.3 \%) \\
\text { Neck }(36 \%) \\
\text { Scalp }(9.3 \%) \\
\text { Distant }(9.3 \%)\end{array}$ & $\begin{array}{l}\text { Nodule (1) } \\
(92 \%) \\
\text { Cyst }(8 \%)\end{array}$ & $\begin{array}{l}16.5 \text { months } \\
\text { NS } 1\end{array}$ & $\begin{array}{l}\text { DOD } 8.5 \text { months } \\
(86 \%)(5) \\
\text { DISS }(14 \%)(1)\end{array}$ \\
\hline Larynx & $\begin{array}{l}57,62 \\
65-71\end{array}$ & $11+3$ & $\begin{array}{l}\text { SCC } 8+3(78 \%) \\
\text { Basaloid SCC } 1 \\
(7 \%) \\
\text { Adeno CA, } 1(7 \%) \\
\text { NEC } 1(7 \%)\end{array}$ & $\begin{array}{l}\text { Chest (23\%) } \\
\text { Scalp (2) } \\
(23 \%) \\
\text { Face (1) }(12 \%) \\
\text { Neck }(12 \%) \\
\text { Distant }(29 \%)\end{array}$ & $\begin{array}{l}\text { Nodules (2) } \\
(90 \%) \\
\text { Carc. erysip } \\
(10 \%) \\
\text { NS (1) }\end{array}$ & 38 months & $\begin{array}{l}\text { DOD } 6.3 \text { months } \\
(54 \%) \\
8 \text { years, } 4 \text { years } \\
\text { DISS }(18 \%) \\
\text { DFS } 19 \text { months } \\
(10 \%) \\
\text { NS (1) }(18 \%)\end{array}$ \\
\hline Nasopharynx & $14,73-76$ & 8 & $\begin{array}{l}\text { NP CA } 7(87.5 \%) \\
\text { Rhabdo } 1(12.5 \%)\end{array}$ & $\begin{array}{l}\text { Face }(18 \%) \\
\text { Neck }(9 \%) \\
\text { Chest }(18 \%) \\
\text { Distant }(54 \%)\end{array}$ & $\begin{array}{l}\text { Nodules }(62.5 \%) \\
\text { 'Mass' }(25 \%) \\
\text { Carc. erysip } \\
(12.5 \%)\end{array}$ & $\begin{array}{l}32 \text { months } \\
\text { Presentation } \\
12.5 \%\end{array}$ & $\begin{array}{l}\text { DOD } 6.4 \text { months } \\
(62.5 \%) \\
\text { DFS } 2 \text { years } \\
(12.5 \%) \\
\text { NS }(25 \%)\end{array}$ \\
\hline $\begin{array}{l}\text { Hypopharynx/ } \\
\text { oropharynx }\end{array}$ & $78-83$ & $6+1$ & $\operatorname{scc} 6+1(100 \%)$ & $\begin{array}{l}\text { Face (18\%) } \\
\text { Scalp (1) } \\
(9.3 \%) \\
\text { Chest }(9.3 \%) \\
\text { NS }(9.3 \%) \\
\text { Distant }(54 \%)\end{array}$ & $\begin{array}{l}\text { Nodule }(57 \%) \\
\text { Plaque }(1) \\
(14 \%) \\
\text { Macule }(14 \%) \\
\text { Necr vasc }(14 \%)\end{array}$ & $\begin{array}{l}23 \text { months } \\
\text { NS } 1\end{array}$ & $\begin{array}{l}\text { DOD } 3.4 \text { months } \\
(50 \%)(3) \\
\text { DFS } 3 \text { months } \\
(17 \%)(1) \\
\text { NS }(25 \%)(2+1)\end{array}$ \\
\hline FNA/scar tract & $7,19-25$ & 9 & $\begin{array}{l}\text { Papillary } 3(30 \%) \\
\text { ACC } 1(10 \%) \\
\text { Follicular } 4(40 \%) \\
\text { Anaplastic } 2(20 \%)\end{array}$ & $\begin{array}{l}\text { FNA tract } \\
(75 \%) \\
\text { Scar }(25 \%)\end{array}$ & Nodule $(100 \%)$ & $\begin{array}{l}37 \text { months (6) } \\
\text { NS (3) }\end{array}$ & $\begin{array}{l}\text { DOD }(22 \%) \\
36.75 \text { months } \\
\text { DUC }(11 \%) \\
1 \text { month } \\
\text { DFS }(33 \%) \\
56 \text { months } \\
\text { DISS }(11 \%) \\
\text { NS }(22 \%)\end{array}$ \\
\hline Average & & $\begin{array}{l}93+12 \\
=105\end{array}$ & & & & $\begin{array}{l}39.2 \text { months } \\
\text { presenting } 14\end{array}$ & $\begin{array}{l}\text { DOD } 7.2 \text { months } \\
\text { from SM } \\
\text { cf FNA/scar DOD } \\
72 \text { months }\end{array}$ \\
\hline
\end{tabular}

NS: Not specified; DFS: Disease-free survival; DISS: Disseminated disease; DOD: Died of disease; DUC: Died of unrelated causes; NEC: Neuroendocrine carcinoma; PLGA: Polymorphous low grade adenocarcinoma; ACC: Adenoid cystic carcinoma; Carc. Erysip: Carcinoma erysipeloides; Necr. vasc: Necrotising vasculitis

has been observed up to 19 and 22 years after initial diagnosis and was the precursor to death in these cases, dying of disease within one year. ${ }^{47}$
Papillary carcinoma metastasizing to skin caused death or dissemination in 10 of 15 cases. Of all thyroid carcinomas, papillary thyroid carcinomas traditionally 
have the best 10 years survival rate of $98 \% .{ }^{50}$ Mean time to death from SM presentation however was only 3.2 months with two cases dying within days of recognising SM. All presentations were nodular except one case with nodules and cysts presenting in the lower neck. ${ }^{48}$ The total $11 / 17(65 \%)$ cases presented with multiple skin sites involved. Three cases involved distal skin sites (lower limb, abdomen) without head and neck skin involvement. ${ }^{36,42,46}$ The time between cancer diagnosis and SM presentation was highly variable mean: 66.8 months (15-132 months).

\section{SALIVARY GLANDS $8,11,13,15,51-59$}

\section{Sites of Metastases}

Salivary gland tumors with associated SM have been reported from 11 major salivary glands (nine parotid, one submandibular, one sublingual), 8,11,13,15,51-54,56-59 and one minor salivary gland. We identified five similar cases in the Mount Sinai database comprising four parotid tumors and one minor salivary gland. A variety of pathology, including adenoid cystic carcinoma (3), acinic cell carcinoma (1), pleomorphic adenoma ex-carcinoma (2), mucoepidermoid carcinoma (1), adenocarcinoma (1) and myoepithelial carcinoma (1), are reported to develop SM from the parotid gland alone. Six cases of salivary gland tumors had metastasized to skin prior to cancer diagnosis which arose from both major and minor glands..$^{8,11,13,55-57}$ Of 29 total SM sites identified, the face was the most common site: $9 / 29$ (31\%). Metastases distant from the head and neck were also common: 8/29 $(27 \%)$. Where SM were observed overlying or close to the primary tumor, these were not contiguous with the primary tumor histologically. In all but one case, ${ }^{57}$ this distinction was clearly made.

\section{Prognosis}

Death or dissemination of disease was seen in $86 \%$ of parotid tumor cases where reported (6/7) and mean time to death from metastatic parotid disease was under 3 months. Of all salivary gland tumors, death from disease occurred in $60 \%$ of those where outcomes were recorded and mean time to death was 5.75 months. More aggressive tumor types did not appear to predict poorer outcomes in this patient group. In fact $2 / 4$ cases of adenoid cystic carcinoma were alive at 20 months, ${ }^{58}$ and disease free at 3 years $^{13}$ from SM presentation.

\section{ORAL CAVITY ${ }^{57,60,61}$}

\section{Sites of Metastases}

Oral cavity cancers metastasizing to skin are documented widely as case series in the literature and all are cases of
SCC. Brownstein and Helwig ${ }^{18}$ found that of 57 cases of oral SCC involving skin; these skin lesions presented in either the neck or the face. Some SM however, have also been noted in the chest. ${ }^{57,62}$ A majority of metastases present as a nodular mass, but have also been found as a cyst. ${ }^{57}$ Yoskovitch ${ }^{6}$ proposed a watershed theory to account for the absence of SM from oral SCC being reported below the diaphragm. Internal metastases below the diaphragm to muscle and kidney, however, have been observed alongside scalp metastases. ${ }^{60}$

\section{Prognosis}

Demarcation between true metastasis and direct tumor extension to skin has not been made in some reviews; however is an important distinction to make. ${ }^{18}$ Cole et $\mathrm{l}^{63}$ demonstrated a significantly worse mean survival from a group with true skin metastasis versus direct extension into skin (3 vs 7 months respectively). The six cases reviewed here in detail show a similarly poor prognosis. Mean time to presentation of SM from cancer diagnosis was 16.5 months and once identified, preceded either death $(86 \%)$ or alive with dissemination $(14 \%)$ in all of these. Time to death from SM was on average 8.5 months which is comparable to larger reviews. Kmucha ${ }^{64}$ and Pitman ${ }^{4}$ observed in noncutaneous SCC of HN from all sites; similar time frames between cancer diagnosis, $\mathrm{SM}$, and almost inevitable death.

Death occurred in all case reports in the current review and all within a year. Pitman ${ }^{4}$ notes survival to be particularly dismal in the group that develop SM even if compared to a similar group that develop distant metastases but not to skin.

\section{LARYNX ${ }^{57,62,65-71}$}

\section{Sites of Metastases}

Laryngeal cancers that metastasize to skin are scarcely reported due to their rarity. Of the 14 cases identified here (11 in previous literature and 3 from our center), SCC predominates (11/14 cases) and in all cases arise on follow-up after cancer diagnosis. Single cases of basaloid SCC, adenocarcinoma, and neuroendocrine carcinoma have also been reported. There is a strong tendency for cancers arising from the larynx to form nodules within the skin with just one exception of inflammatory carcinoma erysipeloides in the lower neck. ${ }^{67}$ Skin metastases from laryngeal cancers have been found regionally in the skin of the neck/chest ${ }^{62}$ and the nasal tip. ${ }^{71}$ They have also been identified at distant skin sites (abdomen, umbilicus, back $)^{57,66,68,70}$ as well as nodular metastases seen in the upper limb/hand..$^{65,69}$ These distant metastases were often found in isolation, sparing any skin of the HN. 


\section{Prognosis}

Mean time to metastasis to skin from diagnosis was 38 months. Following SM, 54\% died of disease (mean 6.3 months) though a further $18 \%$ were alive but with disseminated metastatic disease at the time of reporting. Only a single case showed DFS at 19 months from when the SM presented. Kaplan-Meier survival curves for laryngeal carcinoma show the cumulative decline in survival to $80 \%$ by 50 months follow-up. ${ }^{72}$ The presence of SM dictated a much poorer outcome with only $46 \%$ survival with a maximum follow-up of 23 months.

\section{NASOPHARYNX ${ }^{14,73-76}$}

\section{Sites of Metastases}

The distribution of SM reported from nasopharyngeal tumors appear to be haphazard. These are often seen at distant sites from the head and neck and usually present as nodular masses. Similar to laryngeal cancers, SM from the nasopharynx are usually distant to the head and neck and seen without involvement of the skin of the head or neck. In only one case SM was the presenting problem in a 6 years old female with a subsequent diagnosis of metastatic embryonal rhabdomyosarcoma. ${ }^{14}$ Otherwise these lesions appear in patients during cancer follow-up in an average time of 32 months. ${ }^{14,73-76}$

\section{Prognosis}

Skin metastasis again was a very good prognostic indicator for death which occurred in $62.5 \%$ with mean time to death of 6.4 months of those where outcomes are reported. The expected survival rate in nasopharyngeal carcinoma independent of stage of tumor at diagnosis is close to $50 \%$ after 5 years. ${ }^{77}$ In the current review, survival at 2 years is only $17 \%$.

\section{HYPOPHARYNX/OROPHARYNX ${ }^{78-83}$}

\section{Sites of Metastases}

Tumors of the hypopharynx/oropharynx show similar characteristics to laryngeal and nasopharyngeal cancers when they metastasize to skin. Of the seven cases (all of which are SCC), distant SM predominated (70\%) and, in half of these, these metastases occurred distant from the head and neck in the back ${ }^{81}$ and the abdomen. ${ }^{83}$ Four of seven cases presented as one or more nodules. ${ }^{78,80,82}$ Single reports of macular SM and vasculitic lesions have also been observed from hypopharynx/oropharynx tumors and, in both cases, were found at distant sites in the skin of the back or the abdomen. ${ }^{79,83}$

\section{Prognosis}

Time to SM averaged 23 months from diagnosis and once identified, preceded death by just 3.4 months. Only one case of tonsillar fossa SCC was alive at time of reporting 3 years after SM. Spector ${ }^{84}$ found similar dismal outcomes from a larger review of cases that developed distant metastases from oropharynx/hypopharyngeal cancers. Distant metastases portended a much worse prognosis when compared to regional metastases (6.4 vs $41 \% 5$ years survival respectively).

\section{LIMITATIONS}

Our objective to understand the morphology, pattern of distribution, and morbidity of SM from head and neck cancer was limited to a small case series of 12 patients from a large center, therefore, and an extensive review of the literature was performed. The stage of the disease was rarely reported in case series and reports, which made stratification of risk of developing SM difficult.

As our data set was gathered largely from case reports, follow-up was variable and sometimes absent therefore primary endpoints were not obtainable in 15 cases. The delineation between direct tumor extension and true dermal metastasis is a vital distinction to make as outlined. In cases within our center this was confirmed by a dermatopathologist who carefully excluded cases with continuity with underlying cancer. The literature also usually made this distinction, however was unclear in one case. ${ }^{57}$ Cases of follicular thyroid carcinoma (FTC) presenting with scalp nodules were included in our analysis. It is known that FTC can metastasize to the deep soft-tissues of the scalp and/or skull, thus, sparing the skin itself. Knowledge of this pattern of behavior we believe is important to consider hence inclusion of these cases.

\section{DISCUSSION}

Cutaneous metastasis of noncutaneous head and neck cancers are associated with rapid dissemination of disease and death in a majority of patients. Skin metastases can arise as a presenting complaint or during cancer follow-up (up to 22 years after diagnosis). ${ }^{47}$ We have found the presentation of SM is very commonly nodular. Some less common variations include cysts, plaques and ulcers.

Cancer patients should be made aware to look for changes in the skin on follow-up. This need not be restricted to skin of the head and neck as metastases can occur at very distant sites.

\section{REFERENCES}

1. Hussein MR. Skin metastasis: a pathologist's perspective. J Cutan Pathol 2009. 
2. Lookingbill DP, Spangler N, Sexton FM. Skin involvement as the presenting sign of internal carcinoma: a retrospective study of 7316 cancer patients. J Am Acad Dermatol 1990; 22(1):19-26.

3. Brownstein MH, Helwig EB. Spread of tumors to the skin. Arch Dermatol 1973;107(1):80-86.

4. Pitman KT, Johnson JT. Skin metastases from head and neck squamous cell carcinoma: incidence and impact. Head Neck 1999;21(6):560-555.

5. Herrick BB, et al. Cutaneous metastases in head and neck cancer. Radiation Oncology Investigations 1996;4(4):176-184.

6. Yoskovitch A, et al. Skin metastases in squamous cell carcinoma of the head and neck. Otolaryngol Head Neck Surg 2001;124(3):248-252.

7. Tronnier M, Winzer M, Wolff HH. Cutaneous metastases from follicular thyroid carcinoma: histology, immunohistology, and electron microscopy - a report of two cases. Dermatologica 1991;183(4):286-289.

8. Tan PH, Chew CT, Cheah ES. Malignant mixed tumour arising from minor salivary gland tissue of the right parapharyngeal space with metastasis to the scalp. Ann Acad Med Singapore 1992;21(3):382-385.

9. Caron $\mathrm{P}$, et al. Cutaneous metastasis from follicular carcinoma of the thyroid gland. Thyroid 1993;3(3):235-237.

10. Lissak B, et al. Solitary skin metastasis as the presenting feature of differentiated thyroid microcarcinoma: report of two cases. J Endocrinol Invest 1995;18(10):813-816.

11. Soler E, et al. Malignant pleomorphic parotid adenoma with inflammatory cutaneous metastasis. Br J Dermatol 1996;134(1):190-192.

12. Koller EA, et al. Papillary and follicular thyroid carcinoma metastatic to the skin: a case report and review of the literature. Thyroid 1998;8(11):1045-1050.

13. Makdessian AS, Heathcote JG, Lampe HB. Cutaneous metastasis from a parotid adenoid cystic carcinoma arising in a pleomorphic adenoma. J Otolaryngol 1999;28(3):166-170.

14. Turegun $M$, et al. Nasal tip metastasis of pharyngeal rhabdomyosarcoma. Ann Plast Surg 2001;46(6):656.

15. Srivastava AK, et al. Scalp and intracranial metastasis from pleomorphic adenocarcinoma of the parotid gland. Neurol India 2007;55(4):433-434.

16. Chakraborty J, et al. Cutaneous metastasis from follicular variant of papillary thyroid carcinoma: a case diagnosed on cytology. Ind J Pathol Microbiol 2008;51(1):91-93.

17. Brownstein $\mathrm{MH}$, Helwig EB. Patterns of cutaneous metastasis. Arch Dermatol 1972;105(6):862-868.

18. Brownstein MH, Helwig EB, Metastatic tumors of the skin. Cancer 1972;29(5):1298-1307.

19. Hales MS, Hsu FS. Needle tract implantation of papillary carcinoma of the thyroid following aspiration biopsy. Acta Cytol 1990;34(6):801-804.

20. Panunzi $C$, et al. Cutaneous seeding of a follicular thyroid cancer after fine-needle aspiration biopsy? Diagn Cytopathol 1994;10(2):156-158.

21. Shinohara S, et al. Implantation metastasis of head and neck cancer after fine needle aspiration biopsy. Auris Nasus Larynx 2001;28(4):377-380.

22. Karwowski JK, et al. Needle track seeding of papillary thyroid carcinoma from fine needle aspiration biopsy: a case report. Acta Cytol 2002;46(3):591-595.
23. Abelardo E, et al. Anaplastic thyroid carcinoma implantation after fine needle aspiration cytology. J Laryngol Otol 2007;121(3):268-270.

24. Uchida $\mathrm{N}$, et al. Needle track dissemination of follicular thyroid carcinoma following fine-needle aspiration biopsy: report of a case. Surg Today 2007;37(1):34-37.

25. Bruglia $\mathrm{M}$, et al. Skin and thigh muscle metastasis from papillary thyroid cancer. Singapore Med J 2009;50(2):e61-e64.

26. Barr R, Dann F. Anaplastic thyroid carcinoma metastatic to skin. J Cutan Pathol 1974;1(5):201-206.

27. Auty, RM. Dermal metastases from a follicular carcinoma of the thyroid. Arch Dermatol 1977;113(5):675-676.

28. Bevilacqua $G$, et al. Cutaneous metastasis of a radiationassociated thyroid medullary carcinoma. J Endocrinol Invest 1984;7(6):653-657.

29. Horiguchi $Y$, Takahashi C, Imamura S. Cutaneous metastasis from papillary carcinoma of the thyroid gland: report of two cases. J Am Acad Dermatol 1984;10(6):988-992.

30. Ordonez NG, Samaan NA. Medullary carcinoma of the thyroid metastatic to the skin: report of two cases. J Cutan Pathol 1987;14(4):251-254.

31. DoutreMS, etal.Cutaneous metastasis from papillary carcinoma of the thyroid: a case confirmed by monoclonal antithyroglobulin antibody. Dermatologica 1988;177(4):241-243.

32. Elgart GW, Patterson JW, Taylor R. Cutaneous metastasis from papillary carcinoma of the thyroid gland. J Am Acad Dermatol 1991;25(2 Pt 2):404-408.

33. Toyota $\mathrm{N}$, et al. A case of skin metastasis from follicular thyroid carcinoma. Dermatology 1994;188(1):69-71.

34. Taniguchi $S$, et al. Cutaneous metastases from anaplastic thyroid carcinoma. Int J Dermatol 1996;35(8):574-575.

35. Dahl PR, et al. Thyroid carcinoma metastatic to the skin: a cutaneous manifestation of a widely disseminated malignancy. J Am Acad Dermatol 1997;36(4):531-537.

36. Loureiro MM, et al. An unusual case of papillary carcinoma of the thyroid with cutaneous and breast metastases only. Eur J Endocrinol 1997;137(3):267-269.

37. Prasoon D. Follicular carcinoma of thyroid gland presenting as scalp metastasis. Acta Cytol 1998;42(2):451-452.

38. Boughattas $\mathrm{S}$, et al. Cutaneous metastasis revealing a widely disseminated follicular thyroid carcinoma. Clin Nucl Med 2002;27(5):379-380.

39. Jee MS, et al. Cutaneous metastasis from medullary carcinoma of thyroid gland. Clin Exp Dermatol 2003;28(6):670-671.

40. Aria, Vives FR, Gomez-Dorronsoro ML. Cutaneous nodes in a patient with advanced papillary carcinoma of the thyroid. Clin Transl Oncol 2006;8(9):692-693.

41. Capezzone M, et al. Skin metastases from anaplastic thyroid carcinoma. Thyroid 2006;16(5):513-514.

42. Junik R, et al. Papillary thyroid cancer with metastasis to the skin. Clin Nucl Med 2006;31(7):435-436.

43. Miyoshi I, etal. Papuloerythematous rash due to intralymphatic cutaneous metastasis of cancer. Intern Med 2006;45(2):115-116.

44. Ronga G, et al. Solitary skin metastasis from papillary thyroid carcinoma. Thyroid 2007;17(5):477-478.

45. Agarwal $\mathrm{S}$, et al. Follicular thyroid carcinoma with metastasis to skin diagnosed by fine needle aspiration cytology. Ind J Pathol Microbiol 2008;51(3):430-431.

46. Bucerius J, et al. Papillary thyroid carcinoma with an uncommon spread of hematogenous metastases to the choroid and the skin. J Natl Med Assoc 2008;100(1):104-107. 
47. Santarpia L, et al. Four patients with cutaneous metastases from medullary thyroid cancer. Thyroid 2008;18(8):901-905.

48. Kim HS, et al. Cutaneous metastasis of thyroid cancer presenting as a nodulocystic mass with ulceration. J Dermatol 2009;36(10):559-560.

49. de Giorgi V, et al. Solitary cutaneous metastasis as the first sign of relapse of thyroid carcinoma: a clinical, dermoscopicpathologic case study. Dermatol Surg 2009;35(3):523-526.

50. Gilliland, FD, et al. Prognostic factors for thyroid carcinoma: a population-based study of 15,698 cases from the surveillance, epidemiology and end results (SEER) program 1973-1991 Cancer 1997;79(3):564-573.

51. Smoller BR, Narurkar V. Mucoepidermoid carcinoma metastatic to the skin: an histologic mimic of a primary sweat gland carcinoma. J Dermatol Surg Oncol 1992;18(5):365-368.

52. Thomas KM, Cumberworth VL, McEwan J. Orbital and skin metastases in a polymorphous low grade adenocarcinoma of the salivary gland. J Laryngol Otol 1995;109(12):1222-1225.

53. Tok J, et al. Cutaneous metastasis from a parotid adenocarcinoma. Report of a case with immunohistochemical findings and review of the literature. Am J Dermatopathol 1995;17(3):303-306.

54. Nakamura M, Miyachi Y. Cutaneous metastasis from an adenoid cystic carcinoma of the lacrimal gland. Br J Dermatol 1999;141(2):373-374.

55. Locati LD, et al. Primary high-grade mucoepidermoid carcinoma of the minor salivary glands with cutaneous metastases at diagnosis. Oral Oncology 2002;38(4):401-404.

56. Chang $\mathrm{CH}$, Liao YL, Hong HS. Cutaneous metastasis from adenoid cystic carcinoma of the parotid gland. Dermatol Surg 2003;29(7):775-779.

57. Saeed S, Keehn CA, Morgan MB. Cutaneous metastasis: a clinical, pathological, and immunohistochemical appraisal. J Cutan Pathol 2004;31(6):419-430.

58. Perez DE, et al. Multiple cutaneous metastases from a parotid adenoid cystic carcinoma. Pathol Oncol Res 2007;13(2):167-169.

59. Varsegi MF, et al. Widespread cutaneous metastases from acinic cell carcinoma 20 years after primary presentation. J Cutan Pathol 2008;35(6):591-593.

60. Chuwa WL, Tan YM, Lim DT. Unusual recurrence after chemoirradiation and surgery for squamous cell carcinoma of the tongue. Asian J Surg 2002;25(1):62-65.

61. Marioni G, et al. Skin and eye: uncommon sites of distant metastasis from tongue base squamous cell carcinoma. Acta Otolaryngol 2003;123(9):1110-1114.

62. Danic D, Danic A. Head and neck squamous cell carcinoma skin metastases below of the diaphragm. Acta Dermatovenerol Croat 2003;11(3):153-157.

63. Cole RD, McGuirt WF. Prognostic significance of skin involvement from mucosal tumors of the head and neck. Arch Otolaryngol Head Neck Surg 1995;121(11):1246-1248.

64. Kmucha ST, Troxel JM. Dermal metastases in epidermoid carcinoma of the head and neck. Arch Otolaryngol Head Neck Surg 1993;119(3):326-330.

65. Veraldi $S$, et al. Cutaneous metastases from laryngeal carcinoma. J Dermatol Surg Oncol 1988;14(5):562-564.
66. Horiuchi NH. Tagami skin metastasis in laryngeal carcinoma. Clin Exp Dermatol 1992;17(4):282-283.

67. Bottoni $\mathrm{U}$, et al. Inflammatory cutaneous metastasis from laryngeal carcinoma. Eur J Dermatol 2001;11(2):124-126.

68. Ottinetti A, et al. Cutaneous metastasis of neuroendocrine carcinoma of the larynx: report of a case. J Cutan Pathol 2003; 30(8):512-515.

69. Aydin O, et al. Skin metastasis: an unusual localization from laryngeal carcinoma. Kulak Burun Bogaz Ihtis Derg 2004;12 (3-4):103-106.

70. Dogan G, Kizilay A. Painful cutaneous metastasis in a patient with laryngeal adenocarcinoma. Clin Exp Dermatol 2007;32(2):225-226.

71. Koutis EV, et al. A rare nasal tip skin metastasis of a basaloid squamous cell carcinoma of the larynx. Am J Med 2008;121(9):e3-e4.

72. Tai $\mathrm{P}$, et al. Long-term survival rates of laryngeal cancer patients treated by radiation and surgery, radiation alone, and surgery alone: studied by lognormal and Kaplan-Meier survival methods. BMC Cancer 2005;5:13.

73. Guberman D, Reinus C. Carcinoma erysipelatoides-cutaneous lymphatic vessel spread of a poorly differentiated nasopharyngeal carcinoma. Dermatol Online J 2001;7(2):7.

74. Luk NM, et al. Skin metastasis from nasopharyngeal carcinoma in four Chinese patients. Clin Exp Dermatol 2004; 29(1):28-31.

75. Caloglu M, et al. Nasopharyngeal carcinoma with extensive nodular skin metastases: a case report. Tumori 2006;92(2): 181-184.

76. Tomao F, et al. Axillary and subcutaneous breast metastases from rhinopharyngeal carcinoma: a case report and literature review. Anticancer Res 2008;28(1B):419-423.

77. Rachet $B$, et al. Prognostic factors for mortality in nasopharyngeal cancer: accounting for time-dependence of relative risks. Int J Epidemiol 1998;27(5):772-780.

78. Schultz BM, Schwartz RA. Hypopharyngeal squamous cell carcinoma metastatic to skin.J Am Acad Dermatol 1985;12(1 Pt2): 169-172.

79. Nigro MA, Chieregato G, Castellani L. Metastatic hypopharyngeal carcinoma mimicking necrotizing vasculitis of the skin. Cutis 1992;49(3):187-188.

80. Dasmajumdar SK, et al. Cutaneous metastasis from carcinoma of tonsil. J Postgrad Med 2002;48(1):32-33.

81. Prabhudesai SG, et al. Epidermotropic cutaneous metastases from hypopharyngeal carcinoma. J Otolaryngology 2004;33(3): 198-200.

82. Durvasula VSP, et al. Cutaneous metastases from a hypopharyngeal malignancy. J Laryngology and Otology 2005; 119(4):319-321.

83. Thariat J, et al. Skin metastasis of head and neck carcinoma predictive for dismal outcome. Dermatol Online J 2008;14(6):8.

84. Spector JG, et al. Delayed regional metastases, distant metastases, and second primary malignancies in squamous cell carcinomas of the larynx and hypopharynx. Laryngoscope 2001;111(6):1079-1087. 